\title{
Laxman Karki's Story: A Case on Successful Entrepreneurship
}

\author{
Sushil Kumar Pant*
}

THIS STORY IS ABOUT Laxman Karki, a growing entrepreneur from Pokhara. Laxman Karki was born in a traditional family that inherited enough land to provide food as well as some additional income for the family. Besides farming, Laxman's family members also worked in other jobs that brought additional income to the household.

Laxman's father worked for Nepal Police. Discipline and hard work were part of the family culture. However, business was not in their family's tradition. Laxman worked for the Fishtail Lodge, one of the famous hotels in Pokhara for about two and half years. He learnt some of the business lessons in the hotel which was useful in starting his own business ventures in future.

\section{The Struggle}

When Laxman's father retired from the police service, the family started to look for alternate sources of income. This led him to start a sanitaryware shop in Pokhara in 1982. This was the first business venture for Laxman's family. The sanitaryware business was not successful, and hence was wound up in 1989.

During the 1990s, the carpet manufacturing and exporting to the European countries became one of the fastest growing trades in Nepal. Like many other families with some venture capital Laxman's family also tried its hand in carpet manufacturing. The carpet boom was very short, and to their disappointment, the export started to crumble down due to child labor, inferior quality, and azo-dye related problems in the European market. Moreover, the German carpet market was flooded with cheap imitations from India. Eventually, Laxman closed down the carpet business after two years of running.

Though the two business ventures were not successful he never let his esteem down low due to the failures. He considered the failures as opportunity for learning and continued to fight. In the meantime, he tried his fate in rice-milling. He bought paddy from farmers, milled it and supplied to final consumers. Again the fortune was not in his way and he had to close this venture too after a year. Despite several failures in a short period of time, the fighter inside Laxman never gave up. He started Gandaki Stone Industries, a stone cutting factory in the Pokhara Industrial Estate in 1989. This time he took partners in the business. Four of his friends joined him in this venture. This business seemed viable as Pokhara was growing rapidly as a city that created huge demand for construction material. Moreover, Pokhara mainly used stones as the basic construction material.

The stone cutting and polishing enterprise was successful to some extent. It prompted the Laxman's group to start a new venture by manufacturing concrete paving blocks suitable to pave residential compounds, city footpaths and other public places. This was a unique concept in Nepal. Laxman tried hard without success to convince the then Mayor of Pokhara to use the paving blocks in selected places of Pokhara as demonstration sites so that people would be attracted towards it. Despite lack of encouragement from the public officials, he continued to produce the paving blocks.

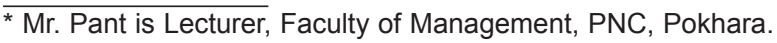




\section{The Journal of Nepalese Business Studies}

In one exhibition that he participated, the then Mayor of Kathmandu Municipality saw the product and was highly interested to use the pavers in some of the pubic places of Kathmandu. So he invited Laxman to shift his factory in Kathmandu or supply the material in large quantities from Pokhara. Unfortunately, Laxman did not have sufficient resources to do either of them and this important opportunity was lost for ever. The concrete pavers venture put Laxman into a personal debt that he borrowed on the mortgage of very valuable agriculture land.

The group finally dropped concrete pavers production and converted the plant into a concrete block manufacturing. Concrete block was the most cheap and popular construction materials in Pokhara. Laxman shifted the plant to Kotre, $20 \mathrm{~km}$ east to Pokhara where sand and gravel, the basic materials used in making concrete block, were easily available at low cost. Laxman was not very satisfied with the block manufacturing venture though he was making some money out of it. There was very stiff competition in this business and as a result of price cutting substandard quality products were being delivered to the consumers. The self-esteem inside him was against such practice. He started looking for alternative ventures where he could make some money and also preserve his self respect.

\section{The Turning Point}

The search for alternative business ended him to realize that he could go for food related business. He thought that food being a basic need there would always be sufficient demand for it. This thought came to him from his inner instinct which he discussed with a long-time friend cum business adviser Yuva Raj Sharma who also encouraged him to go for it. Hence, he started to search for information on any opportunity in food related enterprise.

The first item that came to his mind was production of ginger oil. He had heard from some of his friends that ginger oil has a high value for medicinal and cosmetic uses. In course of searching information, he found that ginger syrup was being produced in Galyang Bazar of Syanja district, which lies south to Pokhara. He visited the ginger syrup factory in Galyang Bazar, where he met a European expert Mr. Rhoden Cheswos, who was working under the Entrepreneurship Development Programme of United Mission to Nepal. Laxman was surprised to know that Mr. Cheswos was training Nepalese entrepreneurs to produce some of the traditional Nepalese foods that included "Gundruk", a popular Nepali food item. This was a kind of 'culture shock" to him that a foreigner was training Nepalese to produce indigenous traditional food items. He thought that a foreigner knows better than us. So it became a turning point for his life and he was now fully committed to enter into traditional food production and marketing.

In 1997, Laxman attended a seminar conducted by the Central Food Lab in Pokhara Chamber of Commerce and Industry (PCCl). One of the conclusions of the seminar was that there could be a niche market for Nepalese traditional food. At that time western and other junk foods were getting very popular among the urban consumers. However, the discussion believed that consumer taste was changing and people were also becoming more health conscious, so the demand for the traditional food would grow in future. Training on marketing research held in $\mathrm{PCCl}$ gave him the confidence to enter into the business. The training was conducted by Prof. Kundan D. Koirala, a prominent marketing guru of Nepal. Prof. Koirala also endorsed the concept as well as helped him to conduct a research for the feasibility of marketing traditional food in Pokhara. The findings of the research were quite encouraging and he had serious conviction to start the business. Unfortunately, he had to face strong resistance from the family members, especially from his wife, Bindu, who was not very convinced about the concept. This was also due to earlier venture failures. Selling food did not appeal her as it is not considered very respectable profession by the society. At 
Laxman Karki's Story: A Case on Successful

this difficult juncture, Yuv Raj came forward and endorsed his idea and encouraged him to go for the project. After persistent efforts for more than a month Bindu barely agreed with the concept and also managed Rs. 10,000 despite their deep financial crisis. They began with seven traditional food items popularly used by Nepalese consumers but were not widely available. The items introduced under the Sital Agro Products were-Kodoko Pitho, Makaiko Pitho, Makaiko Chyankhla, Silam, Bhang seeds, Gundruk, and Chamalko Pitho.

Sital Agro Products was registered on the ownership of Mrs. Bindu Karki. All the items were introduced with one brand name GUNILO which means Good for health. The name was given to Laxman by Prof. Koirala. The production aspect was looked after by Bindu. There was only one helper from outside of the family. Laxman looked after everything else of the venture including collection of raw materials, financial management, distribution and others.

Though the products were ready for marketing they faced a problem in convincing retail stores to carry the products. Most of the retail stores in Pokhara showed very little interest. Fortunately, Omit Supermarket, one of the popular department stores, showed some interest in the products. Mrs. Meena Gurung, the store owner offered the space of his choice inside the store to demonstrate his products. This was a real encouragement for him. Finally, he was able to display and sell those seven products in Omit Supermarket.

Laxman remembers one of the bad experiences in Omit. Though Meena was supportive of his efforts, the salespersons were not very excited about the products. One day when Bindu visited the store she found one salesman threw one of Gunilo products to a corner saying "who would buy these low grade foods". This made her cry with embarrassment. But Laxman managed to console her.

\section{The Success}

Laxman visited several villages and farmers to collect raw food. He traveled extensively across the country for collecting high quality and low price raw materials. These visits also exposed him to many other traditional food items which he later added to his product lines.

Laxman was always committed towards the quality of the product he was processing and supplying to the market. He always emphasized on collecting high quality raw material. For scientific processing and testing he took technical support of Regional Food Lab that officially endorsed the quality of food products. The staffs of the Regional Food Lab were very supportive to Laxman. They were happy to find that a micro entrepreneur was there for their service which was not demanded even by large enterprises.

Laxman also fulfilled the legal requirements of putting the date of manufacture and expiry in all packages to build consumer confidence although the packaging was very basic with very simple labels. The brand name and labels with dates enhanced the image of his products. This changed the attitude of previously skeptical distributors in Pokhara and all big retail stores in Pokhara showed their interest to sell his products. Hence, by the second year of production, majority of the big stores had his products in their shelves.

During the beginning of the venture, the sale from one store was only Rs. 4,000 a month whereas the total cost was Rs. 12,000. Despite this poor state of financial performance, Laxman dared to continue his efforts to produce and sell them. This was because he was quite convinced that the demand for traditional food would grow because of changing lifestyle and growing health consciousness among people. In the second year, the turnover reached around Rs. 10,000 per month with 12 items in the market.

In the third year, one competitor entered the market with some items similar to Laxman's but failed to sell them and finally withdrew. In the fourth year, the items grew to thirty with monthly turnover of around Rs. 50,000. Now many big and small retail stores were interested 


\section{The Journal of Nepalese Business Studies}

to sell his products. However, he was not able to fully meet the demand due to the difficulty in collecting raw materials in large quantities and on regular basis. So he did not want to create problem for himself by selling from several outlets and not being able to supply when demanded.

The fifth year was the year of great success. The monthly sales crossed Rs. 100,000 for the first time which was really a great achievement for an entrepreneur having a history of failures and humble beginning. The number of products offered to the market also increased to fifty items.

In the sixth year the product varieties offered further were increased to eighty and the monthly turnover was about Rs. 150,000. This year Laxman also started his own retail outlet in a popular market center. The purpose of opening the own outlet was to reach near to the customer and collecting first hand information about their likes and dislikes. He tells that the retail outlet has not only increased the total sales but also helped greatly to introduce several products which are now very popular among customers.

Currently, (the seventh year) the monthly sales are around Rs. 200,000 with more than hundred food and related items. In the mean-time one new enterprise also has been established Gandaki Agro Packers in order to sell grain and spice related products and cover larger segment of the market.

\section{Laxman's Marketing Strategy}

Laxman delivers his products directly to the retail stores. Currently, thirty-two retail shops sell his products. The self owned outlet named "Green House: a diversity shop" also sells most of his products. Laxman says that he does not have to face any big marketing problem except small scale competition.

However, he is aware of the fact that any big business house of Pokhara may see the profit prospect and enter into the market with big bang. This may pose a great challenge to him. But he is not scared of this possibility. He is confident that big business houses will not be able to offer the wide variety and also ensure the quality of the product. Hence, he intends to fight prospective competition, big or small, by ensuring the quality of the product and low profile marketing. He intends to remain number one with relationship marketing. He is in direct contact with his customers that include households, hotels, and restaurants. He has also cultivated a very good habit of listening to their complaints and new ideas. However, he is also skeptical about his capacity to generate sufficient resources to cover large market area. He is particularly hesitating to enter Kathmandu market.

He places consumer prices on his labels so that all stores charge equally to customers for his products. He is very particular on this aspect and ensures this by personal visit to the outlets. The terms and conditions of sales, the commission, and profit margins are negotiated separately with individual retailers based on the sales record and past performances.

The company has very limited advertising in Pokhara's local newspapers and FM radio. It participates in all demonstrations and exhibitions organized in Pokhara for marketing purpose. The media has also supported him by not only publishing the news but also by writing features about Laxman, Bindu and the products. Laxman especially wants to mention the name of Amrit Bhadgaunle of Kantipur daily for his continuous support. He is also very much satisfied with the coverage about his efforts and the products received in local media. All of them greatly helped promote the products. However, his most reliable source of marketing has always been the word of mouth from satisfied customers. For this, the company always focuses on the quality of the product. In addition, Laxman also has implemented a rule that if a customer comes with any complaint about the product, the retailer should take back the product and make full refund without any question and report to him. And then, he 
Laxman Karki's Story: A Case on Successful

collects back the product and makes necessary tests to find out the reason behind the complaint.

\section{The Future}

The major problem being faced by the enterprise is regular and reliable source of high quality raw materials. Though he is traveling a lot for such a source and also using some agents to ensure the supply, the success is less than satisfactory. For this he is also taking help of LIBIRD, a local non-governmental organization, which is not only helping Laxman for conducting research to find out the nutritional value of the products but also to establish contacts with farmers from hills and terai. LIBIRD is also helping to develop some new uses of the traditional foods to fit into the modern day demand of the consumers.

The most worrying challenge being faced is to increase the volume of production for which he needs to install some plants. Though they do not cost much, but because of the backlog of previous failures he has still not been able to manage necessary funds for expansion. He is shy of going to financial institutions because they will not finance based only on the viability of the project but ask for collateral such as land, building. He seems to be haunted by previous failures that might have stopped him to mortgage his fixed assets.

Laxman still dreams of entering into the Kathmandu market with huge demand for his products. But before doing this, he wants to ensure the regular supply of raw materials and processed products. Entering Kathmandu now may be a strategically wrong move. It may give idea to many venture capitalists and invite unnecessary potential competitors.

His future plans include exporting selected items to Nepali Diaspora. He believes that this market segment will heartily welcome his products with their emotional connection to Nepal and the Nepalese culture. The final stage of his future plan is to export limited items to the global market, particularly to those countries where Nepalese have migrated and settled permanently.

\section{The Philosophy}

When asked what continuously drove him to the adventure of creating new enterprises as well as coming up with the idea of selling traditional foods, he says, "Though I lost a lot of money in my previous ventures and once I had planned to go abroad to make my future, I always believed that I have to do something on my own and continue to work hard. I believed that despite all those failures I can make my mark in business. I also had the thought that whatever I do I have to be within top ten in the field. Besides, I also tried to create a strong platform for my children so that they will not have to face the difficulties that I faced in my life". All these were Laxman's aspirations which he seems have been able to achieve to a greater extent. 